\begin{tabular}{|l|l|l|}
\hline \multicolumn{2}{|c|}{ PublisherInfo } \\
\hline \hline PublisherName & $:$ & BioMed Central \\
\hline \hline PublisherLocation & $:$ & London \\
\hline \hline PublisherImprintName & $:$ & BioMed Central \\
\hline \hline
\end{tabular}

\title{
Proteome analysis of breast cancer cells (8701-BC) cultured from primary ductal infiltrating carcinoma: relation to correspondent breast tissues
}

\begin{tabular}{|l|l|l||}
\hline \multicolumn{2}{|c||}{ ArticleInfo } \\
\hline \hline ArticleID & $:$ & 31 \\
\hline \hline ArticleDOI & $:$ & $10.1186 /$ bcr31 \\
\hline \hline ArticleCitationID & $:$ & E004 \\
\hline \hline ArticleSequenceNumber & $:$ & 13 \\
\hline \hline ArticleCategory & $:$ & Non-peer-reviewed research \\
\hline \hline ArticleFirstPage & $:$ & 1 \\
\hline \hline ArticleLastPage & $:$ & 23 \\
\hline \hline & & RegistrationDate : 1999-11-8 \\
ArticleHistory & $:$ & Received \\
\hline ArticleCopyright & $:$ & Current Science Ltd1999-11-8 \\
\hline \hline ArticleGrants & $:$ & \\
\hline \hline ArticleContext & $:$ & 130582211 \\
\hline \hline
\end{tabular}


Loredana Basiricò, Aff1

Luca Bini, Aff4

Simona Fontana, ${ }^{\text {Aff3 }}$

Vitaliano Pallini, ${ }^{\text {Aff4 }}$

Salvatore Minafra, Aff2 Aff3

Ida Pucci-Minafra, ${ }^{\text {Aff1 Aff3 }}$

Aff1 Department of Cell Biology and Development, University of Palermo, Italy

Aff2 Institute of Histology, University of Palermo, Italy

Aff3 Centre of Exp. OncoBiology, University of Palermo, Italy

Aff4 Department of Molecular Biology, University ofSiena, Italy

\section{Statement of finding}

The two-dimensional gel electrophoresis represents a unique tool of analysing expression levels of a thousand proteins simultaneously and to compare the protein profiles of a given cell in a worldwide dimension. In addition, the recent programs developed for cross-comparing gel images, even from different laboratories, offer the possibility to evaluate homologies and differences between affine maps. By Melanie-assisted analyses and access to Swiss-2DPAGE database, we have detected the proteomic profile of the 8701-BC cell line, deriving from a primary DIC, which represents the most common type of breast cancer. The cell-line map was compared by gel matching with that of DIC biopsy available on line, and within the large area of overlapping, some of the corresponding spots were identified and quantified. To our knowledge this is the first attempt to correlate the pattern of protein expression of a cell line derived from a primary tumor with the corresponding tissue. The results are of great interest from at least two point of view: firstly, the 8701-BC cell line retains the dominant luminal phenotype of the breast epithelium, which expresses predominantly cytokeratins -8 and -18; secondly the proteomic profile of the cell line appears highly homologous to the "in vivo" counterpart. In particular, a panel of 28 peptides, showing a higher expression in the DIC tissue with respect to the normal counterpart, displays the same, or even more robust signature in the cancer cells. This group of peptides, mainly belonging to stress protein family and to metabolic enzymes, may be considered as tumor markers of peculiar pertinence of neoplastic cells, rather than of stromal components, and representative, if not exclusive, of breast carcinoma.

\section{Keywords}




\section{Abstract}

\section{Background}

The term "proteome" was introduced by Wilkins and collaborators in 1996, to indicate the total number of proteins expressed by a given genome.Proteins represent the functional aspect of gene activities and support thephenotypic identity of cells. In addition, physiological modulation andqualitative or quantitative alterations in gene expression, due to pathologicalconditions, including neoplasia, can be monitored by the study of proteinexpression. A powerful tool for the evaluation of the global protein complementexpressed by a given cytotype, is the high-resolution 2D-electrophoresis (andrelated techniques) which allows the simultaneous separation of severalhundreds of polypeptides (including polypeptides corresponding topost-translation modifications). Using appropriate identification markers andcomputer-processing tools, master maps are constructed for intra-lab andonline comparison of 2D samples. This approach can be used to complementinformation based on nucleic acid analysis, since some genes may betranscribed, but not necessary translated into proteins and therefore thenumber of mRNA copies does not ultimately reflects the number of functionalprotein per cell. In addition, the number of protein species in eukaryoticcells is greatly increased by alternative splicing at the transcriptional leveland by a wide variety of post-translational modifications. The biologicalaspects of carcinogenesis involve a number of gene products which is difficultto predict "a priori", therefore the proteomic approach may be of great utilityto search for set of tumor markers which, collectively, may be representativeof a given neoplasia.

\section{Objectives}

To define the pattern of protein expression of the cell line8701-BC, established from a primary ductal infiltrating carcinoma of humanbreast (DIC), and to compare it with that of a correspondent breast cancertissue, in order to identify relevant differences and homologies between the"in vivo" and "in vitro" situations. The interest for the $8701-\mathrm{BC}$ cell line ismainly due to its derivation from a primary breast cancer, and thereforeconsisting of cell population not yet exposed to the metastatic selection

\section{Methods}


Two Dimensional Gel Electrophoresis: the isoelectrofocusing (firstdimension) was carried out on an $18 \mathrm{~cm}$ non linear Immobiline strip, $\mathrm{pH}$ range3-10; for the second dimension the proteins were separated on an SDS 9-16\%linear polyacrylamide gradient. Silver-stained gels were digitized using acomputing densitometer and processed with the Melanie computer system(Bio-Rad); gel calibration was carried out on the basis of internal standards. The ExPaSy molecular biology server of the Geneva University Hospital and theUniversity of Geneva (http://www.expasy.ch) was applied to compute theoreticalelectrophoretic parameters.

\section{Protein Sequencing}

N-terminal microsequencing of selected spots was performed byautomated Edman degradation in an Applied Biosystem protein sequenator(Procise, Perkin-Elmer), after electrotransfer of the 2D gels ontopolyvinylidene difluoride membranes. SWISS-PROT + TREMBL databases and BLITZ(bic sw) devices were used to search for on-line sequence similarity.

\section{Results}

The proteomic profile of the 8701-BC cell line has been studiedand compared with the tissue counterpart. Within an analysis window comprisingabout 1811 discernible spots, 64 peptides have been so far identified, by meansof gel matching, subcellular localization and microsequencing. The spots, towhich an identity was assigned, were grouped into 4 categories according totheir general functions: a) cytoskeletal proteins, b) proteins of cellmetabolism and biosynthesis, c) chaperones and other functionally-relatedproteins, d) peptides and enzymes with regulatory functions. A fifth groupconsists of peptides with unknown identity.

Following protein assignment, homologies (presence/absence) andrelative differences with previously identified proteins of human breast DICtissue and its histologically health-tissue (HT) counterpart, have beensearched. By the use of computer-assisted tools, a composite map between2D-gels of the 8701-BC cell line and of the DIC tissue was produced, the formermatching with the latter by a percentage of about $62 \%$. Furthermore, within aset of 32 peptides showing higher abundance in DIC versus HT breast tissue, 28exhibited a higher relative abundance also in the cell-line proteome, and 18out the 28, were still more represented in the cell line than in the DIC. Thelatter group includes stress proteins (calrecticulin, collagen binding protein2, protein disulfide isomerase, peptidyl prolyl cis-trans isomerase A, GRP78,GRP 94, HSP60), enzymes of metabolic pathways (glyceraldehyde 3-phosphatedehydrogenase, fructose bisphosphate aldolase and the cytochrome C oxydase VA),tubulin 2 and seven peptides with unknown identity. On the contrary, 4 peptides(MIF, thioredoxin and two unknown peptides) appeared less represented in thecell line with respect to the biopsy. Finally, 13 new spots, undetected in DICtissue map, were assigned to the proteomic map of the 8701-BC cells. Among thisgroup we identified ATP synthase b chain, mitocondrial 60S ribosomal protein(L7/L12), annexin I, galectin 1, proteasome $\mathrm{Z}$ subunit, elongation factor $\mathrm{Tu}$, and 2 peptides not present in the data bank. 


\section{Conclusion}

The proteomic fingerprint of the 8701-BC cell line appears highlyhomologous to the "in vivo" counterpart. Firstly, cells retain the dominantluminal phenotype of the breast epithelium, which expresses predominantlycytokeratins -8 and -18 . In addition a panel of 28 peptides, showing a higherexpression in the DIC tissue with respect to the normal counterpart, displaysthe same, or even more robust signature in the cancer cells. This group ofpeptides, mainly belonging to stress protein family and to metabolic enzymes,may be considered as tumor markers of peculiar pertinence of neoplastic cellsrather than of stromal components, and representative, if not exclusive, ofbreast carcinoma.

\section{Introduction}

Among the invasive hystotypes, ductal infiltrating carcinoma (DIC) is the most aggressive form of breast cancer and accounts for $70 \%$ to $80 \%$ of all breast cancers [1]. This kind of carcinoma has usually a poor prognosis, and represents the standard histotype with which the other less frequent subtypes (i.e. papillary, mucinous-colloid, tubular, medullary carcinomas) are compared (see: http://www.erinet.com/ fnadoc/images/pathol-1/breast/hist.htm).

In contrast to the high multiplicity of breast cancer, the present knowledge on the molecular mechanisms involved in the dramatic changes from normal breast cells into different types of breast neoplasms, is still fragmentary. This appears particularly evident when the number of tumor-related features, available for clinical treatment of patients with breast cancer (i.e. status of steroid hormone receptors, growth factors, individual oncogenes and their products) is compared with the number of the putative genes having a role or causing cancer.

According to recent estimation [2] the size of human aploid genome is about $3000 \mathrm{Mbp}$, encoding from 50,000 to 100,000 genes. Of these only a certain percentage, from $10 \%$ to $20 \%$ are believed to be expressed and translated into proteins in a given phenotype. Some genes may be transcribed, but not necessary translated into proteins, therefore the number of mRNA copies does not ultimately reflects the number of functional protein per cell [3]. Therefore focusing on the protein complement of a given cell type, may provide substantial information on qualitative and quantitative aspects of gene expression, complementary to that supplied by the mRNA based technology.

The high resolution 2D-IPG is at present the only tool for scientists, in order to detect a large number of proteins at once on the same cell preparation, without prior knowledge of their nature or identity, each cellular pattern being like a fingerprint, essentially unique among an unlimited number of distinguishable possibilities.

Within the restrictions of 2D-IPG technology, due to the size of the analysis window (excluding the peptides with mass below 10,000 $\mathrm{Da}$, and those with isoelectric point $>$ 9) proteomic analyses represent a growing field of research for monitoring changes in gene activity, applied e.g. to the study of 
functional genomics, phenotypic modulation, molecular pharmacology of cancer, for which a number of human cancer cell lines are currently used (see,e.g.: http://www.anl.gov/CMB/PMG; http://www.nci.nih.gov/intra/lmp/jnw/Prot.htm).

Among the breast cancer cell lines so far described in literature, 8701-BC [4] deserves particular interest, since it was established from a primary DIC, while, due to the difficulty to remove the surrounding connective tissue without affecting cell viability, the majority of breast cancer cells are derived from late-phase metastatic pleural effusions (see, e.g.,http://www.anl.gov:80/BIO/PMG/ projects/).

The aim of present work was to define a pattern of protein expression characteristic of the cell line 8701-BC, and to compare it, by computer-processing tools, with the protein profiles of a correspondent breast cancer tissue, in order to identify relevant differences and homologies between the two images. It is well known that the interdynamic space-temporal interactions of neoplastic cells with extracellular matrix (ECM) and stromal cells, can affect cellular behaviours (e.g. growth rate [5, 6], apoptosis [7], motility $[8,9,10]$, protease release [11], etc.) and therefore may influence gene expression and protein synthesis, through a cascade of signals difficult to predict a priori. Thus the comparison between protein expression of isolated cancer cells and of a corresponding tumoral hystotype may greatly contribute to better define some properties and metabolic attitude of the neoplastic cells in absence of regulatory effects of tissutal origin. Obviously this approach, owing the complexity of the system and the great number of proteins forming the proteomic profile, can be faced stepwise, focusing on selected set of peptides.

In the present study, within an analysis window comprising about 1811 discernible spots we have at present catalogued 64 peptides, by means of gel matching, subcellular localisation and microsequencing of selected spots.

After protein assignment, we searched for qualitative (presence/absence) and relative differences, with previously identified proteins of human breast DIC tissue and its histologically health-tissue (HT) counterpart [12] by using the integrated approach offered by proteomic 2D PAGE databases and Melanie tools. We therefore produced a composite map, between 2D-gels of the 8701-BC cell line and of the DIC tissue, the former matching for about $62 \%$ with proteomic profile of the DIC. More interestingly, the evaluation of differences in spot abundance (calculated as percentage of volume of individual spots over the sum of total spot volumes in each map) demonstrated that within a set of 32 peptides, showing higher abundance in DIC Vs HT breast tissue, 28 displayed a higher relative abundance also in the cell-line proteome, with respect to the HT biopsy. Furthermore 18 spots out the 28 , were still more abundant in the cell line than in the DIC. The latter group includes stress proteins and enzymes involved in metabolic pathways, some of which have been found overexpressed in several tumor tissues [12] tubulin b2 and seven peptides with unknown identity. On the contrary, 4 peptides (MIF, thioredoxin and two unknown peptides) appeared less represented in the cell line with respect to the biopsy.

This suggests that the panel of 28 peptides, showing a more robust signature both in the cancer tissue and in the cell proteome, may be considered of peculiar pertinence of neoplastic cells, even in the absence of other tissutal components. Finally, 13 new spots, which were not detected in DIC tissue map, were assigned to the proteomic map of the 8701-BC cells. 
We trust that this integrated approach of direct assays and computer-assisted data analysis, extended to additional groups of proteins and proteomics, will be of great utility for construction of comprehensive databases of tumor markers, from neoplastic cells and tissues, and for the development of strategies in anticancer drugs and other applicative field of the cancer research.

\section{Materials and methods}

Cell Culture. For the experiments described, we have utilized the neoplastic cell line 8701-BC at passages 22 th. The cells were seeded at the concentration of $1-2 \times 10^{5} / \mathrm{cm}^{2}$; culture medium was RPMI 1640 (GIBCO, Paisley, U.K.), supplemented with 10\% foetal calf serum (FCS; GIBCO) and antibiotics (100 units/ml penicillin and $100 \mathrm{mg} / \mathrm{ml}$ streptomycin), in a humidified incubator with $3 \% \mathrm{CO}_{2}$ in air at $37^{\circ} \mathrm{C}$.

Sample Preparations. 8701-BC cells were grown to confluence and then incubated with three changes of serum-free RPMI-medium (30 min, $1 \mathrm{~h}$ and $24 \mathrm{~h}$ ). After washing with ice cold phosphate buffered saline (PBS), they were carefully scraped and incubated in RIPA buffer (50 mM Tris pH 7.5, 1\% Nonidet P-40, 0.1\% deoxycholate, $150 \mathrm{mM} \mathrm{NaCl}, 4 \mathrm{mM}$ EDTA, 0.01\% aprotinin, $10 \mathrm{mM}$ sodium pyrophosphate, $2 \mathrm{mM}$ sodium orthovanadate, $1 \mathrm{mM}$ PMSF) on ice for $30 \mathrm{~min}$. The total cellular lysate was centrifuged at 14,000 rpm for $8 \mathrm{~min}$ to clear cell debris. An aliquot of the lysate was removed and saved for determination of protein concentration, and the remainder was dialysed against distilled water, lyophilized and subsequently submitted to electrophoretic analyses.

Subcellular Fractionation. Confluent 8701-BC cells were washed twice with cold PBS containing 0.5 $\mu \mathrm{M}$ sodium orthovanadate and scraped into a hypotonic lysis buffer, HBL (10 mM Tris pH 7.4, $10 \mathrm{mM}$ $\mathrm{NaCl}, 3 \mathrm{mM} \mathrm{MgCl}$, $1 \mathrm{mM}$ EDTA, $1 \mathrm{mM}$ ethylene glycol-bis (b-amino-ethyl ether)-N,N,N',N'tetraacetic acid (EGTA), $1 \mathrm{mM}$ sodium orthovanadate, $10 \mathrm{mM}$ sodium pyrophosphate, $1 \mathrm{mM}$ PMSF, 10 $\mu \mathrm{g} / \mathrm{ml}$ aprotinin, $10 \mathrm{mM} \mathrm{NaF}$ ). The cells were incubated on ice for $10 \mathrm{~min}$ and homogenized (40 strokes) in a tight-fitting Dounce homogenizer. The total fraction was separated into nuclear and postnuclear fractions by centrifugation at $375 \mathrm{x}$ g for $5 \mathrm{~min}$. The postnuclear fraction was centrifuged again at low speed for $10 \mathrm{~min}$ to remove nuclear contamination and then subjected to high speed centrifugation at $150,000 \mathrm{x} g$ for $30 \mathrm{~min}$. The pellet (membrane fraction) was washed with HBL and the supernatant (cytosolic fraction) was centrifuged again at high speed to remove membrane contamination. All fraction were resuspended with $50 \mathrm{mM}$ Tris $\mathrm{pH}$ 7.4, $100 \mathrm{mM} \mathrm{NaCl}, 3 \mathrm{mM} \mathrm{MgCl} 2,1 \mathrm{mM}$ EDTA, $1 \mathrm{mM}$ EGTA, $10 \mathrm{mM}$ sodium orthovanadate, $10 \mathrm{mM}$ sodium pyrophosphate, $1 \mathrm{mM} \mathrm{PMSF}, 10 \mu \mathrm{g} / \mathrm{ml}$ aprotinin, $50 \mathrm{mM} \mathrm{NaF}, 0.5 \%$ deoxycholate, $0.1 \%$ SDS, $0.2 \%$ Nonidet P-40, and then centrifuged at $12,000 \times \mathrm{g}$ for $15 \mathrm{~min}$ to remove insoluble material. All procedures were performed on ice. Protein concentrations were determined using a BCA protein assay (PIERCE).

Two Dimensional Gel Electrophoresis. Aliquots of cell preparations were separated using the Immobiline-polyacrylamide system as described by Görg et al. [13] and Bjellqvist et al. [14]. The isoelectrofocusing (first dimension) was carried out on an $18 \mathrm{~cm}$ non linear Immobiline strip, $\mathrm{pH}$ range 3-10 (Pharmacia). Strips were rehydrated in $8 \mathrm{M}$ urea, 2\% CHAPS, $10 \mathrm{mM} \mathrm{DTE}$ and 0.8\% carrier ampholytes (Resolyte 3.5-10, BDH) and a trace of bromophenol blue. Forty five mg of total protein were dissolved in $8 \mathrm{M}$ urea, 4\% CHAPS, $40 \mathrm{mM}$ Tris, $65 \mathrm{mM}$ DTE and then applied to the cathodic end 
of the gel strip submerged in paraffin oil. Voltage was linearly increased from 300 to $3500 \mathrm{~V}$ during the first $3 \mathrm{~h}$, then stabilized at $5000 \mathrm{~V}$ for $20 \mathrm{~h}$. After the run the IPG strips were equilibrated in $6 \mathrm{M}$ urea, $30 \%$ glycerol, $2 \%$ SDS, $0.05 \mathrm{M}$ Tris-HCl pH 6.8, 2\% DTE for $12 \mathrm{~min}$, then in the same urea/SDS/Tris buffer solution but substituting the 2\% DTE with 2.5\% iodoacetamide. For the second dimension the proteins were separated on an SDS 9-16\% linear polyacrylamide gradient until the bromophenol blue front had reached the bottom of the gel, at a constant current of $40 \mathrm{~mA} / \mathrm{gel}$ and $10^{\circ} \mathrm{C}$. Gels were stained with ammoniacal silver nitrate as described by Hochstrasser et al. [15].

Electrotransfer. For the electrotransfer the proteins were separated by preparative 2D-PAGE, for the run $1.5 \mathrm{mg}$ of proteins was applied, with the in-gel sample rehydration procedure according to Sanchez et al. [16], to the commercially available IPG strips. After the second-dimensional electrophoresis, gels were equilibrated in $10 \mathrm{mM}$ 3-cyclohexylamino-1-propanesulphonic acid (CAPS), pH 11, plus 10\% methanol and the proteins were electrotransferred onto polyvinylidene difluoride membranes (Bio-Rad), at a constant voltage of $100 \mathrm{~V}$. Membranes were stained with Coomassie Blue, to visualize protein spots to be subjected to microanalysis, and scanned.

Image Acquisition and Data Analysis. Silver-stained gels were digitized using a computing densitometer (Molecular Dynamics 300S, 4000X5000 pixels; 12 bits/pixel) and processed with the Melanie 2.1 and 2.2 computer system (Bio-Rad) on a SUN SPARC station; gel calibration was carried out on the basis of internal standards [14]. The ExPaSy World Wide Web (WWW) molecular biology server of the Geneva University Hospital and the University of Geneva (http://www.expasy.ch) was applied to compute theoretical electrophoretic parameters (http://www.expasy.ch/tools/pi-tool.html). Quantitative variations of proteins were expressed as volumes of spots (i.e. integration of optical density over the spot area). In order to correct for differences in gel staining, relative volumes to the sum of the volume of all spots in each gel were calculated with the Melanie system.

Gel Matching. The basic gel matching algorithm consists of comparing two gel images and finding pairs of related features, by comparing their respective positions and sizes, that is, spots representing the same protein in both gels. Spots of main proteins, occurring both in 8701-BC cells breast and in breast biopsy gels were used as landmarks to match images. Matching was then extended to the colorectal epithelia cell and human liver reference maps in SWISS-2DPAGE database (http://www.expasy.ch/ ch2d/ch2d-top.html).

Sequence Analyses. Protein sequencing was performed by automated Edman degradation in an Applied Biosystem protein sequenator (Procise, Perkin-Elmer), using the TFA conversion program provided by the manufacturer. SWISS-PROT + TREMBL databases and BLITZ (bic sw) devices were used for on-line sequence similarity (search at http://www.expasy.ch/tools/).

\section{Results}

General properties of 8701-BC cells. Figure 1(A, B, C, D) shows four typical growth stages of the 8701-BC cells, seeded atthe concentration of $1-2 \times 10^{5} / \mathrm{cm}^{2}$, namely:1A) low density (24h after seeding), 1B) medium density (48h), 1C) confluence (72h), and 1D) overconfluence (1 week). 
Figure 1 Micrographs of 8701-BC cells at different times from seeding A, low density (24h after seeding); B, medium density (48h); C, confluence (72h) and D, overconfluence (one week). 600X

[MediaObjects/13058_1999_Article_31_Fig1_HTML.jpg]

Morphological and karyotypic features, growth rates and some immunocytochemical properties, have been already reported [4]. As shown in fig. 1A the cell shape at seeding is rather elongated; after completion of cell adhesion (1B-1C), cells acquire pleomorphic morphology, displaying a large cell body with a prominent nucleus and one or two nucleoli, an irregular outline of the cell surface, and propensity to form spikes [4] and shed vesicles [7]. After confluence the cells do not show contact inhibition and overgrow forming "domes" (fig. 1D), even at low level of serum. Briefly the main characteristics of the cell line, so far detected, are the followings:i) karyotype with 55-60 chromosomes per cell, with numerous rearrangements; c-myc not amplified [4]; ii) positive staining of all cells with the specific epithelial cell markers carcinoembryonic antigen (CEA), tissue polypeptide antigen (TPA) and cytokeratin 8, and negative reaction for HLA antigens [4] and oestrogen receptors m-RNA [18]; iii) expression and secretion of urokinase and a panel of MMPs and their tissue inhibitors (TIMP1 and TIMP2) [11, 19] and expression of some tumor-related cytokine m-RNAs (TGFb 1,-2, -3, and PTHrP) [20]; iiii) a moderate invasive potential, both "in vitro" and "in vivo" [19,20] which is enhanced by the tumoral collagen $\mathrm{OF} / \mathrm{LB}$, previously detected by some of us [22, 23]. Different substrates for cell culture, also drastically modulate cell morphology and growth rate [6, 9, 24, 25], as well as MMPs production (11).

Proteomic analysis of 8701-BC cells. For the present study cells were taken at confluence. After scraping the flask, as described in "Materials and Methods"the cell lysate was submitted to the assay for total protein contents and aliquots of $45 \mu \mathrm{g}$ applied to the 2D-IPG electrophoresis as described. The assay was reproduced at least three times with identical results.

Figure 2 shows a typical 2D electrophoretogram of proteins from 8701-BC cell lysate. This image describes the polypeptides that fall within the experimental window of pI 4-9 and 10-200 kDa and are sufficiently abundant to be detected by the silver-staining procedure. A total of ca 1811 spots were counted by the Melanie software, some of which grouped into isoelectric series, conceivably generated by post-translational modifications.

Figure 2 Representative 2D electrophoretogram (silver staining) of proteins in 8701-BC cell line. Red arrows indicate spots assigned by gel matching, green arrows indicate spots assigned by Nterminal microsequencing. Circles indicate spots which are little detectable in the printed image.

[MediaObjects/13058_1999_Article_31_Fig2_HTML.jpg]

In particular 64 proteins were catalogued in the map of cells 8701-BC:53 spots (red arrows) have be assigned by image-matching to reference 2D maps of human proteins from epithelial tissues and tumors, available in Siena laboratory (breast) and in Internet (colon, keratynocytes and liver). Eleven spots were N-terminal microsequenced, after transfer of the gel into Immobilon PVDF membranes (green arrows). The 64 proteins were grouped into five categories and listed in tables from 1 to 5. Data reported in the table columns, from right to left are: description of the protein; the method of protein identification (reference 2D map or N-terminal microsequencing); protein accession number in SWISS-PROT database; experimental and theoretical (in parentheses) $\mathrm{pI}$ and $\mathrm{Mr}$ values. Discrepancies between 
experimental and calculated electrophoretic values are expected, since the theoretical values do not comprehend post-translational modifications. Some proteins occur as isoelectric series, whose experimental extreme $\mathrm{pI}$ values are reported.

\section{Show Char Content Hide Char Content}

Table 1 Cytoskeletal proteins

\begin{tabular}{|l|l|c|c|c|c|}
\hline $\begin{array}{c}\text { Spot } \\
\mathrm{N}^{\circ}\end{array}$ & \multicolumn{1}{|c|}{ Protein description } & $\begin{array}{c}\text { Method of protein } \\
\text { ID }\end{array}$ & $\begin{array}{c}\text { SWISS-PROT } \\
\text { AC }\end{array}$ & p I & MrkDa \\
\hline 1 & $\beta$ actin & GM (Li, Br) & P02570 & $\begin{array}{c}5.16 \\
(5.29)\end{array}$ & $42(41.7)$ \\
\hline & $\beta$ actin & GM (Li, Br) & P02570 & $\begin{array}{c}5.20 \\
(5.29)\end{array}$ & $42(41.7)$ \\
\hline & $\beta$ actin & GM (Li, Br) & P02570 & $\begin{array}{c}5.23 \\
(5.29)\end{array}$ & $42(41.7)$ \\
\hline 2 & CK 8, Cytokeratin 8 & GM (K, Br) & P05787 & $\begin{array}{c}5.35 \\
(5.52)\end{array}$ & $\begin{array}{c}49.2 \\
(53.5)\end{array}$ \\
\hline 3 & CK 18, Cytokeratin 18 & GM (K, Br) & P05783 & 5.31 & 42.8 \\
& & & & $(5.34)$ & $(47.9)$ \\
\hline 4 & Tubulin $\beta 2$ chain & GM (Br) & P05217 & 4.98 & 51.6 \\
& & & & $(4.79)$ & $(49.8)$ \\
\hline 5 & Tubulin $\beta 2$ chain & GM (Li, Br) & P05217 & 5.27 & 31.2 \\
fragment) & & & $(4.79)$ & $(49.8)$ \\
\hline
\end{tabular}

$\mathrm{GM}=$ gel matching; Li=liver; $\mathrm{Br}=$ breast; $\mathrm{K}=$ keratynocytes.

\section{Show Char Content Hide Char Content}

Table 2 Proteins involved in cell metabolism and biosynthesis

\begin{tabular}{|l|l|c|c|c|c|}
\hline $\begin{array}{c}\text { Spot } \\
\mathrm{N}^{\circ}\end{array}$ & \multicolumn{1}{|c|}{ Protein description } & $\begin{array}{c}\text { Method of } \\
\text { protein ID }\end{array}$ & $\begin{array}{c}\text { SWISS-PROT } \\
\text { AC }\end{array}$ & $\mathrm{p} I$ & MrkDa \\
\hline 6 & ATP synthase $\beta$ chain & GM (C) & P06576 & $\begin{array}{c}5.03 \\
(4.93)\end{array}$ & $\begin{array}{c}49.5 \\
(49.1)\end{array}$ \\
\hline 7 & Eytochrome C oxidase polypeptide VA & GM(Li, Br) & P20674 & $\begin{array}{c}4.90 \\
(4.88)\end{array}$ & $\begin{array}{c}12.4 \\
(12.5)\end{array}$ \\
\hline 8 & Enoyl-CoA hydratase, short chain & GM (Li, Br) & P30084 & $\begin{array}{c}5.89 \\
(5.63)\end{array}$ & $\begin{array}{c}25.4 \\
(28.3)\end{array}$ \\
\hline 9 & Elongation factor 1 $\beta$ & GM (Li, Br) & P24534 & $\begin{array}{c}4.62 \\
(4.50)\end{array}$ & $\begin{array}{c}29.2 \\
(24.6)\end{array}$ \\
\hline 10 & Elongation factor Tu & Nt-microseq. & P49411 & $6.5(6.8)$ & $\begin{array}{c}43.3 \\
(43.4)\end{array}$ \\
\hline
\end{tabular}




\begin{tabular}{|c|c|c|c|c|c|}
\hline$\overline{11}$ & Fructose bisphosphate aldolase & $\overline{\mathrm{GM}(\mathrm{Br})}$ & 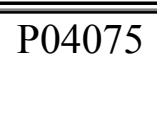 & $\begin{array}{l}7.95 \\
(8.39)\end{array}$ & $\begin{array}{c}38.1 \\
(39.3)\end{array}$ \\
\hline & Fructose bisphosphate aldolase & $\overline{\mathrm{GM}(\mathrm{Br})}$ & $\mathrm{P} 04075$ & $\begin{array}{c}7.74 \\
(8.39)\end{array}$ & $\begin{array}{c}38.1 \\
(39.3)\end{array}$ \\
\hline \multirow[t]{2}{*}{12} & Glutamate dehydrogenase 1 & $\mathrm{GM}(\mathrm{Li}, \mathrm{Br})$ & P00367 & $\begin{array}{c}6.76 \\
(6.71)\end{array}$ & $\begin{array}{l}50.1 \\
(56)\end{array}$ \\
\hline & Glutamate dehydrogenase 1 & $\mathrm{GM}(\mathrm{Li}, \mathrm{Br})$ & P00367 & $\begin{array}{c}6.88 \\
(6.71)\end{array}$ & $\begin{array}{l}50.1 \\
(56)\end{array}$ \\
\hline 13 & Glutathione S-transferase P & $\mathrm{GM}(\mathrm{Li}, \mathrm{Br})$ & P09211 & $\begin{array}{c}5.43 \\
(5.44)\end{array}$ & $\begin{array}{c}23.3 \\
(23.2)\end{array}$ \\
\hline \multirow[t]{2}{*}{14} & $\begin{array}{l}\text { Glyceraldehyde 3-phosphate } \\
\text { dehydrogenase }\end{array}$ & $\mathrm{GM}(\mathrm{Li}, \mathrm{Br})$ & P04406 & $\begin{array}{c}8.14 \\
(8.58)\end{array}$ & $\begin{array}{c}35.3 \\
(35.9)\end{array}$ \\
\hline & $\begin{array}{l}\text { Glyceraldehyde 3-phosphate } \\
\text { dehydrogenase }\end{array}$ & $\overline{\mathrm{GM}}(\mathrm{Li}, \mathrm{Br})$ & $\overline{\text { P04406 }}$ & $\begin{array}{c}8.54 \\
(8.58)\end{array}$ & $\begin{array}{c}35.3 \\
(35.9)\end{array}$ \\
\hline 15 & $\begin{array}{l}\text { Mitochondrial 60S ribosomal protein } \\
\text { L7/L12 }\end{array}$ & $\overline{\mathrm{GM}(\mathrm{C})}$ & P52815 & $\begin{array}{c}5.08 \\
(5.01)\end{array}$ & $\begin{array}{c}17.1 \\
(17.4)\end{array}$ \\
\hline 16 & $\begin{array}{l}\text { PGDH, 15-Hydroxyprostaglandin } \\
\text { dehydrogenase }\end{array}$ & $\mathrm{GM}(\mathrm{Li}, \mathrm{Br})$ & P15428 & $\begin{array}{c}5.58 \\
(5.56)\end{array}$ & $\begin{array}{l}24.8 \\
(29)\end{array}$ \\
\hline 17 & $\begin{array}{l}\text { Phosphatidylethanolamine-binding } \\
\text { protein }\end{array}$ & $\overline{\mathrm{GM}}(\mathrm{Li}, \mathrm{Br})$ & P30086 & $\begin{array}{c}7.46 \\
(7.43)\end{array}$ & $\begin{array}{c}19.6 \\
(20.9)\end{array}$ \\
\hline 18 & Possible cytidilate kinase & $\mathrm{GM}(\mathrm{Li}, \mathrm{Br})$ & P30085 & $5.37(-)$ & $21.2(-)$ \\
\hline 19 & Superoxide dismutase & $\mathrm{GM}(\mathrm{Li}, \mathrm{Br})$ & P04179 & $\begin{array}{c}6.96 \\
(6.86)\end{array}$ & $\begin{array}{c}21.6 \\
(22.2)\end{array}$ \\
\hline 20 & Superoxide dismutase $(\mathrm{Cu}-\mathrm{Zn})$ & $\mathrm{GM}(\mathrm{Li}, \mathrm{Br})$ & P00441 & $\begin{array}{c}5.42 \\
(5.70)\end{array}$ & $\begin{array}{c}15.5 \\
(15.8)\end{array}$ \\
\hline \multirow[t]{2}{*}{21} & Triosephosphate isomerase & $\mathrm{GM}(\mathrm{Li}, \mathrm{Br})$ & P00938 & $\begin{array}{c}6.50 \\
(6.51)\end{array}$ & $\begin{array}{c}25 \\
(26.5)\end{array}$ \\
\hline & Triosephosphate isomerase & $\mathrm{GM}(\mathrm{Li}, \mathrm{Br})$ & P00938 & $\begin{array}{c}6.81 \\
(6.51)\end{array}$ & $\begin{array}{c}25 \\
(26.5)\end{array}$ \\
\hline
\end{tabular}

\section{Show Char Content Hide Char Content}

Table 3 Folding proteins / Chaperons / Heat shock

\begin{tabular}{|l|l|c|c|c|c|}
\hline $\begin{array}{c}\text { Spot } \\
\mathrm{N}^{\circ}\end{array}$ & \multicolumn{1}{|c|}{ Protein description } & $\begin{array}{c}\text { Method of protein } \\
\text { ID }\end{array}$ & $\begin{array}{c}\text { SWISS-PROT } \\
\text { AC }\end{array}$ & $\mathrm{p} I$ & MrkDa \\
\hline 22 & Calreticulin & GM (Br) & P27797 & $\begin{array}{c}4.52 \\
(4.29)\end{array}$ & $\begin{array}{c}59.3 \\
(46.5)\end{array}$ \\
\hline 23 & Collagen binding protein 2 & GM (Br) & P50454 & $9.0(8.95)$ & $\begin{array}{c}48.2 \\
(44.6)\end{array}$ \\
\hline 24 & ERP 31 & GM (Li, Br) & P30040 & $\begin{array}{c}5.67 \\
(6.96)\end{array}$ & $\begin{array}{c}26.1 \\
(25.9)\end{array}$ \\
\hline
\end{tabular}




\begin{tabular}{|c|c|c|c|c|c|}
\hline \multirow[t]{2}{*}{$\overline{25}$} & GRP 75 & GM (Li, Br) & P38646 & $\begin{array}{c}5.24 \\
(5.51)\end{array}$ & $\begin{array}{c}68.3 \\
(68.9)\end{array}$ \\
\hline & GRP 75 & $\mathrm{GM}(\mathrm{Li}, \mathrm{Br})$ & P38646 & $\begin{array}{c}5.30 \\
(5.51)\end{array}$ & $\begin{array}{c}68.3 \\
(68.9)\end{array}$ \\
\hline \multirow[t]{3}{*}{26} & GRP 78 & GM (Br) & P11021 & $\begin{array}{c}4.99 \\
(4.98)\end{array}$ & $\begin{array}{c}73.1 \\
(70.3)\end{array}$ \\
\hline & GRP 78 & $\mathrm{GM}(\mathrm{Br})$ & P11021 & $\begin{array}{c}5.02 \\
(4.98)\end{array}$ & $\begin{array}{c}73.1 \\
(70.3)\end{array}$ \\
\hline & GRP 78 & $\mathrm{GM}(\mathrm{Br})$ & P11021 & $\begin{array}{c}5.04 \\
(4.98)\end{array}$ & $\begin{array}{c}73.1 \\
(70.3)\end{array}$ \\
\hline \multirow[t]{3}{*}{27} & HSP 60 , Heat shock protein 60 & $\overline{\mathrm{GM}}(\mathrm{Li}, \mathrm{Br})$ & P10809 & $\begin{array}{c}5.17 \\
(5.24)\end{array}$ & $59.5(58)$ \\
\hline & HSP 60 , Heat shock protein 60 & $\overline{\mathrm{GM}}(\mathrm{Li}, \mathrm{Br})$ & P10809 & $\begin{array}{c}5.21 \\
(5.24)\end{array}$ & $59.5(58)$ \\
\hline & HSP 60 , Heat shock protein 60 & $\overline{\mathrm{GM}}(\mathrm{Li}, \mathrm{Br})$ & P10809 & $\begin{array}{c}5.27 \\
(5.24)\end{array}$ & $59.5(58)$ \\
\hline \multirow[t]{3}{*}{28} & PDI, Protein disulfide isomerase & $\overline{\mathrm{GM}}(\mathrm{Li}, \mathrm{Br})$ & P07237 & $\begin{array}{c}4.81 \\
(4.69)\end{array}$ & $\begin{array}{c}56.7 \\
(55.3)\end{array}$ \\
\hline & PDI, Protein disulfide isomerase & $\overline{\mathrm{GM}}(\mathrm{Li}, \mathrm{Br})$ & P07237 & $\begin{array}{c}4.84 \\
(4.69)\end{array}$ & $\begin{array}{c}56.7 \\
(55.3)\end{array}$ \\
\hline & PDI, Protein disulfide isomerase & $\overline{\mathrm{GM}}(\mathrm{Li}, \mathrm{Br})$ & P07237 & $\begin{array}{c}4.86 \\
(4.69)\end{array}$ & $\begin{array}{c}56.7 \\
(55.3)\end{array}$ \\
\hline \multirow[t]{3}{*}{29} & $\begin{array}{l}\text { Peptidyl prolyl cis-trans } \\
\text { isomerase A }\end{array}$ & $\overline{\mathrm{GM}}(\mathrm{Li}, \mathrm{Br})$ & P05092 & $\begin{array}{c}6.66 \\
(7.82) \\
\end{array}$ & $\begin{array}{c}14.5 \\
(17.9) \\
\end{array}$ \\
\hline & $\begin{array}{l}\text { Peptidyl prolyl cis-trans } \\
\text { isomerase A }\end{array}$ & $\overline{\mathrm{GM}}(\mathrm{Li}, \mathrm{Br})$ & P05092 & $\begin{array}{r}7.07 \\
(7.82) \\
\end{array}$ & $\begin{array}{c}14.5 \\
(17.9) \\
\end{array}$ \\
\hline & $\begin{array}{l}\text { Peptidyl prolyl cis-trans } \\
\text { isomerase A }\end{array}$ & $\mathrm{GM}(\mathrm{Li}, \mathrm{Br})$ & P05092 & $\begin{array}{c}7.51 \\
(7.82)\end{array}$ & $\begin{array}{c}14.5 \\
(17.9)\end{array}$ \\
\hline 30 & Tumor rejection antigen, GRP 94 & $\mathrm{GM}(\mathrm{Br})$ & P14625 & $\begin{array}{c}4.90 \\
(4.73)\end{array}$ & $\begin{array}{c}91.2 \\
(90.2)\end{array}$ \\
\hline
\end{tabular}

For abbreviations see Table 1 and Table 2

\section{Show Char Content Hide Char Content}

Table 4 Peptide/ Enzymes with regulatory function

\begin{tabular}{|l|l|c|c|c|c|}
\hline $\begin{array}{l}\text { Spot } \\
\mathrm{N}^{\circ}\end{array}$ & Protein description & $\begin{array}{c}\text { Method of } \\
\text { protein ID }\end{array}$ & $\begin{array}{c}\text { SWISS-PROT } \\
\mathrm{AC}\end{array}$ & $\mathrm{p} I$ & MrkDa \\
\hline 31 & Annexin I & Nt-microseq. & P04083 & 8.08 & 30.7 \\
\hline 32 & Cathepsin D & GM (Li, Br) & P07339 & $\begin{array}{c}5.26 \\
(5.56)\end{array}$ & $\begin{array}{c}28.2 \\
(26.6)\end{array}$ \\
\hline & Cathepsin D & GM (Li,Br) & P07339 & $\begin{array}{c}5.49 \\
(5.56)\end{array}$ & $\begin{array}{c}28.2 \\
(26.6)\end{array}$ \\
\hline
\end{tabular}




\begin{tabular}{|l|l|c|c|c|c|}
\hline 33 & Galectin 1 & GM (C) & P09382 & $\begin{array}{c}5.0 \\
(4.93)\end{array}$ & $\begin{array}{c}12.4 \\
(12.1)\end{array}$ \\
\hline 34 & $\begin{array}{l}\text { MIF, Macrophage migration inhibitory } \\
\text { factor }\end{array}$ & GM (Br) & P14174 & 7.62 & 11.9 \\
$(8.24)$ & $(12.3)$ \\
\hline 35 & Proteasome, Z subunit & Nt-microseq. & P28066 & 4.77 & 25.9 \\
& & & & $(4.69)$ & $(26.5)$ \\
\hline 36 & TCTP, Translationally controlled tumor & GM (Li, Br) & P13693 & 4.89 & 22.1 \\
& protein & & & $(4.84)$ & $(19.6)$ \\
\hline 37 & Thioredoxin & GM (Li, Br) & P10599 & $\begin{array}{c}4.90 \\
(4.82)\end{array}$ & $\begin{array}{c}11.6 \\
(11.6)\end{array}$ \\
\hline 38 & Ubiquitin & GM (Li, Br) & P02248 & 6.89 & $8.7(8.6)$ \\
& & & & $(6.56)$ & \\
\hline
\end{tabular}

For abbreviations see Table 1 and Table 2

\section{Show Char Content Hide Char Content}

Table 5 Unknown peptides

\begin{tabular}{|l|l|c|c|c|c|}
\hline Spot N & Protein description & Method of protein ID & SWISS-PROT AC & $\mathrm{p} \mathrm{I}$ & $\mathrm{MrkDa}$ \\
\hline 39 & ---- & $\mathrm{GM}(\mathrm{Br})$ & & 6.52 & 133.8 \\
\hline 40 & ---- & $\mathrm{GM}(\mathrm{Br})$ & & $6.65-6.80$ & 87.7 \\
\hline 41 & ---- & GM (Br) & & 6.1 & 74.6 \\
\hline 42 & N-BLOCKED & Nt-microseq. & & 6.51 & 60.4 \\
\hline 43 & GM (Br) & & 7.48 & 57.8 \\
\hline 44 & ----- & GM (Br) & & 8.80 & 47.5 \\
\hline 45 & ---- & GM (Br) & & 7.65 & 41.7 \\
\hline 46 & ---- & GM (Br) & & 8.01 & 41.4 \\
\hline 47 & ULAG (fragment) & GM (Li, Br) & P31933 & $5.46(-)$ & $38.3(-)$ \\
\hline 48 & QRQDAQAXQ & Nt-microseq. & & 6.78 & 34.9 \\
\hline 49 & ---- & GM (Br) & & 7.68 & 32.9 \\
\hline 50 & HLFQRHRDG & Nt-microseq. & & 5.25 & 32.7 \\
\hline 51 & N-BLOCKED & Nt-microseq. & & 8.34 & 31.5 \\
\hline 52 & ---- & GM (Br) & & 4.82 & 29.7 \\
\hline 53 & N-BLOCKED & Nt-microseq. & & 8.19 & 27.9 \\
\hline 54 & N-BLOCKED & Nt-microseq. & & 6.77 & 26.3 \\
\hline 55 & ULA6, 24 kDa protein & GM (Li, Br) & P30041 & $6.32(6.02)$ & $25.3(24.9)$ \\
\hline 56 & ULA7 (fragment) & GM (Li, Br) & P30042 & $6.98(-)$ & $23.6(-)$ \\
\hline 57 & ---- & GM (Br) & & 6.09 & 21.7 \\
\hline 58 & ---- & GM (Br) & & 5.79 & 17.0 \\
\hline 59 & AYVADLDQ & Nt-microseq. & & 7.75 & 15.7 \\
\hline 60 & ----- & GM (Br) & & 8.47 & 15.5 \\
\hline 61 & ---- & GM (Br) & & 7.55 & 15.1 \\
\hline
\end{tabular}




\begin{tabular}{|l|l|c|l|c|c|}
\hline 62 & N-BLOCKED & Nt-microseq. & & 5.08 & 14.6 \\
\hline 63 & --- & $\mathrm{GM}(\mathrm{Br})$ & & 8.17 & 13.1 \\
\hline 64 & ---- & $\mathrm{GM}(\mathrm{Br})$ & & 5.88 & 11.0 \\
\hline
\end{tabular}

For abbreviations see Table 1 and Table 2; ULA:unknown protein from 2D PAGE of liver tissue.

Subcellular protein distribution. In order to evaluate the distribution of the global protein content of 8701-BC lysate into the cytosolic or membranous compartments, the total cellular lysate was submitted to fractionation as described in "Materials and Methods"and an equal amount of proteins ( $45 \mu \mathrm{g})$ was loaded into parallel gels. Figures 3 A and B show the electrophoretograms (2D maps) of peptides derived respectively from cyto-membrane (A) and cytosol (B) fractions. As expected the two maps reflect the markedly different distribution of some major spots (e.g., tubulin, actin, protein-disulfide isomerase), due to the enrichment operated by the cell fractionation.

Figure 3 Two electrophoretograms of subcellular fractionation of 8701-BC cells: A (cyto-membrane fraction) and B (cytosol fraction). The spots corresponding to the 38 identified proteins (table 1,2,3,4) are indicated with arrows. The spots corresponding to peptides that segregate preferentially in one of the two fractions are named and pointed with arrows in each electrophoretogram. The unknown peptides (see table 5) are not indicated. Circles indicate spots not detected in the map of the total cell lysate and at present not identified.

[MediaObjects/13058_1999_Article_31_Fig3_HTML.jpg]

A quantitative definition of the distribution of any given spot is provided by the ratio of abundances in the two subcellular fractions. Membrane/cytosol abundance ratios for assigned spots are reported in Tables 6 and agree with literature data on the subcellular localization of many of these proteins. In fact, cytosolic proteins exhibit a ratio $<1$, while proteins associated with membranes (endoplasmic reticular proteins, mitochondrial enzymes) have a $>1$ ratio. According to the values observed, some proteins appear more strongly associated to the membrane fraction (among these the ATP-synthase, ERP 31, PDI), while other proteins expected in the membrane fraction, are partly recovered in the cytosol (as for the L7/L12 peptide). Moreover, as a consequence of protein enrichment upon cell fractionation, the presence of some spots not detected in the whole cell map, was observed in both fractions (circles in the map).

\section{Show Char Content Hide Char Content}

Table 6 Subcellular distribution of 8701-BC proteins

\begin{tabular}{|c|c|c|c|c|c|}
\hline \begin{tabular}{|l} 
PROTEIN \\
DESCRIPTION
\end{tabular} & $\begin{array}{l}\% \text { in } \\
\text { Vol } \\
\text { MB/ } \\
\text { CT }\end{array}$ & LOCALIZATION & $\begin{array}{c}\text { PROTEIN } \\
\text { DESCRIPTION }\end{array}$ & $\begin{array}{c}\% \text { in } \\
\text { Vol } \\
\text { MB/ } \\
\text { CT }\end{array}$ & LOCALIZATION \\
\hline Annexin I & 3.6 & & GRP 78 & 3.1 & $\overline{\text { ER }}$ \\
\hline $\begin{array}{l}\text { ATP synthase } \beta \\
\text { chain }\end{array}$ & 5.6 & MIT & $\begin{array}{c}\text { HSP } 60 \text {, Heat shock } \\
\text { protein } 60\end{array}$ & 1.8 & MIT \\
\hline
\end{tabular}




\begin{tabular}{|c|c|c|c|c|c|}
\hline$\beta$ actin & 0.38 & CYT & $\begin{array}{c}\text { MIF, Macrophage } \\
\text { migration inhibitory factor }\end{array}$ & 0.06 & CYT \\
\hline Calreticulin & 2.96 & ER & $\begin{array}{c}\text { Mitochondrial 60S } \\
\text { ribosomal protein L7/L12 }\end{array}$ & 0.03 & MIT \\
\hline Cathepsin D & 0.52 & LYS & $\begin{array}{l}\text { PDI, Protein disulfide } \\
\text { isomerase }\end{array}$ & 3.4 & ER \\
\hline $\begin{array}{l}\text { CK 8, Cytokeratin } \\
8\end{array}$ & 0.9 & CYT & $\begin{array}{l}\text { Peptidyl prolyl cis-trans } \\
\text { isomerase A }\end{array}$ & 0.49 & CYT \\
\hline \begin{tabular}{|l} 
CK 18, \\
Cytokeratin 18
\end{tabular} & 0.28 & CYT & $\begin{array}{c}\text { PGDH, } \\
\text { 15-Hydroxyprostaglandin } \\
\text { dehydrogenase }\end{array}$ & 0.11 & CYT \\
\hline $\begin{array}{l}\text { Collagen binding } \\
\text { protein } 2\end{array}$ & 1.5 & $\overline{E R}$ & $\begin{array}{c}\text { Phosphatidylethanolamine- } \\
\text { binding protein }\end{array}$ & 0.16 & $\overline{\mathrm{CYT}}$ \\
\hline $\begin{array}{l}\text { Cytochrome C } \\
\text { oxidase } \\
\text { polypeptide VA }\end{array}$ & 2.7 & $\overline{\mathrm{MIT}}$ & Possible cytidilate kinase & 0.5 & \\
\hline $\begin{array}{l}\text { Elongation factor } \\
1 \beta\end{array}$ & 0.6 & & Proteasome, $\mathrm{Z}$ subunit & CYT & \\
\hline $\begin{array}{l}\text { Elongation factor } \\
\mathrm{Tu}\end{array}$ & 4.08 & MIT & & & \\
\hline $\begin{array}{l}\text { Enoyl-CoA } \\
\text { hydratase, short } \\
\text { chain }\end{array}$ & 1.1 & MIT & Superoxide dismutase & 8 & MIT \\
\hline \begin{tabular}{|l} 
ERP 31, \\
Endoplasmic \\
reticulum protein
\end{tabular} & 5.5 & $\overline{E R}$ & $\begin{array}{c}\text { Superoxide dismutase }(\mathrm{Cu}- \\
\mathrm{Zn})\end{array}$ & 0.17 & CYT \\
\hline \begin{tabular}{|l} 
Fructose \\
bisphosphate \\
aldolase
\end{tabular} & 0.5 & CYT & $\begin{array}{l}\text { TCTP, Translationally } \\
\text { controlled tumor protein }\end{array}$ & 0.59 & CYT \\
\hline Galectin 1 & 1.3 & $\mathrm{CS}$ & Thioredoxin & 0.51 & \\
\hline \begin{tabular}{|l} 
Glutamate \\
dehydrogenase 1
\end{tabular} & 2.8 & MIT & Triosephosphate isomerase & 0.4 & \\
\hline \begin{tabular}{|l} 
Glutathione S- \\
transferase P
\end{tabular} & 6.8 & & Tubulin $\beta 2$ chain & 0.4 & CYT \\
\hline $\begin{array}{l}\text { Glyceraldehyde } \\
\text { 3-phosphate } \\
\text { dehydrogenase }\end{array}$ & 0.6 & CYT & $\begin{array}{c}\text { Tumor rejection antigen, } \\
\text { GRP } 94\end{array}$ & 1.5 & $\overline{E R}$ \\
\hline GRP 75 & 1.17 & MIT & Ubiquitin & 0.2 & $\mathrm{CYT} / \mathrm{NU}$ \\
\hline
\end{tabular}

Comparison with tumoral and non-tumoral breast tissues and relative quantification of selected peptides. The Research group of Siena laboratory has previously presented a reference two-dimensional gels from frozen slices of human breast ductal carcinoma and its histologically normal counterpart. The study was conducted on ten different patients with DIC of histological grade from I to III. Careful analyses were performed under the microscope in order to select comparable tissue areas, free of 
necrotic, fat or inflammatory and fibrous tissues, and showing comparable amount of epithelial and nonepithelial contents [12]. The Authors found that protein expression profiles in DIC and in HT appeared to be similar, except for a pattern consisting of 32 spots, which were highly expressed in all carcinoma specimens, and less intense and occasionally undetectable in normal tissue. This difference was statistically significant (from $\mathrm{p}<0,001$ to $\mathrm{p} 0,01$ or $\mathrm{p} 0,05$ ) and prompted as to search for analogies and differences between the cell line 8701-BC and the tumor biopsy, in the assumption that protein expression pertinent to the neoplastic cells would be enriched in the map of the cell line.

The comparative analyses were conducted under identical conditions (sample loading, size of the electrophoretic chambers and IPG systems) in order to allow computer assisted procedure for qualitative matching and relative quantification of selected spots. By merging features from the two gels (1811 detected in cell map and 2602 in the DIC map) the matching resulted on 1116 pairs of features, corresponding respectively to a percentage of cross-overlapping of about $62 \%$ (cell/DIC) and of $42 \%$ (DIC/cell). This values appear highly representative when considering that a number of spots corresponding to tissutal components of the biopsy were absent in the map of 8701-BC cells.

In fig. 4 is presented a "synthetic gel" constructed after gel matching of the breast DIC biopsy (available by Internet at http://www.bio-mol.unisi.it/2d/2d.html) with that of the 8701-BC cells. In the synthetic gel are indicated the spots of corresponding peptides to which an identity was assigned. In the histogram in fig. 5 are reported the relative \% of volumes (mean of triplicate measurements) of the 32 spots forming the differentially expressed protein pattern between DIC and HT. As it can be observed, 28 spots out of 32, show a higher relative abundance in the cell-line proteome, with respect to the HT biopsy. Furthermore 18 spots out the 28, appear still more abundant in the cell line than in the DIC. On the contrary, 4 peptides (MIF, thioredoxin and two unknown peptides) appear less represented in the cell line with respect to the biopsy (both tumoral and non-tumoral).

Figure 4 Synthetic gel created by merging features from 2D gel of 8701-BC cells with that from DIC biopsy (available by internet at http://www.bio-mol.unisi.it/2d/2d.html and reported in reference 12). The number of features detected within the analysis window were 1811 in the cell map and 2602 in the DIC map. The gel matching resulted on 1116 pairs of features, corresponding respectively to a percentage of cross-overlapping of about $62 \%$ (cell/DIC) and of $42 \%$ (DIC/cell). The feature labels on the synthetic gel bear the same numbers as in figure 2, and correspond to spots common to the two original gels. Clusters of corresponding spots are surrounded by contours.

[MediaObjects/13058_1999_Article_31_Fig4_HTML.jpg]

Figure 5 The relative abundances of a group of 32 spots, forming a pattern of differentially expressed proteins between DIC and HT biopsy (reference 12), are compared with that of corresponding spots in the map of 8701-BC cells. The numbers in the abscissa correspond to the spots indicated in figures 2 and 4 . The values in the $y$-axis represent $\%$ of volume (integration of OD over the feature's area) of individual spots over the sum of total spot volumes in each map. The differences observed between DIC and HT biopsies were statistically significant according to the Mann-Whittney test with $p<0.001$ for spots $4,7,11,14,22,23,26,28,30,37,44,47,60,61,64$, and $p<0.01$ or 0.05 for the rest (see ref.12).

[MediaObjects/13058_1999_Article_31_Fig5_HTML.jpg] 


\section{Discussion}

The two-dimensional gel electrophoresis technique represents a unique tool of analysing expression levels of a thousand proteins simultaneously and to compare the protein profiles of a given cell in a world-wide dimension. In addition, the recent programs developed for cross-comparing gel images, even from different laboratories, offer the possibility to evaluate homologies and differences between affine maps. By Melanie-assisted analyses and access to Swiss-2DPAGE database, we have detected the proteomic profile of the 8701-BC cell line, deriving from a primary DIC, which represents the most common type of breast cancer. The cell-line map was compared by gel matching with that of DIC biopsy available on line, and within the large area of overlapping, some of the corresponding spots were identified and quantified.

Out of the 1811 spots detected by Melanie in the gel, at present 64 were catalogued by means of gel matching, cell fractionation and microsequencing. The spots, to which an identity was assigned, were grouped into 4 categories according to their general functions. A fifth group consists of peptides with unknown identity.

The first group includes cytoskeletal proteins. The spots assigned to this category are 3 actin isoforms, cytokeratin- 8 and -18 and tubulin $\mathrm{b} 2$. The latter shows a relative increment of about 4.5 times respect to the non-tumoral tissue. Since tubulin is involved in cell division, this increment may be related with the increased proliferation rates of the neoplastic cells, but other possible roles, played by tubulin in the neoplastic cell behaviour, cannot be excluded. Concerning cytokeratins, this class of intermediate filament protein is widely used as markers of phenotype, and it is interesting to note that 8701-BC cells appear to retain "in vitro" the dominant luminal phenotype of the breast epithelium, which expresses predominantly cytokeratins -8 and -18 , whereas the basal layer is made up of cells mainly positive for cytokeratin-14 [26].

The second group comprehends proteins involved in cell metabolism and biosynthesis. Among these, the glyceraldehyde 3-phosphate dehydrogenase (GAPDH), the fructose bisphosphate aldolase and the cytochrome $\mathrm{C}$ oxydase (VA) were found relatively enriched in the cell map, when compared with the DIC tissue. Note that these enzymes belong to the group of proteins differentially expressed in the DIC tissue versus the normal counterpart, with high significant statistical index [12]. These findings are in agreement with other literature data, since the two glycolytic enzymes show increased level of transcription in cancer tissue and highly-proliferating cells [27] [28]. Some Authors have also correlated the increased level of GAPDH with cell motility and metastatic potential of prostatic cancer cells [28]; similarly the cytochrome $\mathrm{C}$ oxydase (VA) was found up-regulated in prostate carcinoma cells and tissues and therefore considered a useful marker for studying the alteration of energy metabolism in cancer cells and for the diagnosis of prostate cancer [30].

The third group includes "chaperones" and other functionally related proteins and enzymes. Many chaperone proteins are also stress or heat-shock proteins, whose rate of synthesis accelerates many folds in several cell-disturbing conditions. In our map we have observed a group of 9 endoplasmic reticular proteins, 7 of which are more represented with respect to the DIC tissue. In particular the stressinducible glycoprotein of $47 \mathrm{kDa}$, a collagen specific molecular chaperone [31] acting as an ERretention signal [32], is at least 13 times more abundant in cell map respect the non-tumoral tissue. 
Recently, it has been reported that tumor cell lines derived from metastatic carcinomas, and still metastatic in animals, synthesise higher levels of HSP47; accordingly, it has been suggested a promoting role for HSP47 in tumor metastasis and its possible use as a prognostic marker for the metastatic propensity of human tumor cells [33]. These findings are in good agreement with previous work of some of us [34], showing that $8701-\mathrm{BC}$ cells are able to produce collagen chains.

The IV group is composed of peptides and enzymes with regulatory functions. Among these: macrophage migration inhibitory factor (MIF), thioredoxin, cathepsin D (CD), translationally controlled tumor protein (TCTP, or P23), proteasome/ubiquitine complex, galectin 1, and annexin I. The MIF is one of the first lymphokine discovered, which is also involved in various cellular processes, other than immunity, and recently described to be associated with prostate tumor [12] and breast cancer. However the exact role of MIF in normal tissue and cancer is not known. The thioredoxin is a redox protein with growth factor activity, that modulates the activity of several proteins important for cell growth, and it has been reported to be overexpressed in a number of human primary cancers [36]. Moreover, thioredoxin function has been demonstrated to be necessary in maintaining the transformed phenotype by experimental introduction of a dominant-negative mutant gene into a breast cancer cell line [37]. The $\mathrm{CD}$ is an oestrogen-dependent lysosomal protease that is synthesised by normal tissues; it has been found overexpressed and secreted at high levels in one third of breast cancers. Its secreted precursor has mitogenic activity and in an acid environment is able to degrade basement membranes. For these properties $\mathrm{CD}$ is regarded as a factor facilitating invasion and metastasis of breast cancer [1, 38] . However present analysis does not show variations in the level of CD expression between cell and tissues. Similarly the translationally controlled tumor protein (TCTP, or P23), a protein, which has been found to be preferentially expressed in some type of tumor, cells during the early growth phase [39, 40], is also expressed in the HT at same extent. The physiological function of TCTP is still unknown. On the contrary the relative abundance of MIF and thioredoxin in the 8701-BC cells was found lower to that of the DIC biopsy, suggesting that the expression of these two peptides is more pertinent to the whole cancer tissue than to the neoplastic cells by themselfes.

The proteasome is a multicatalytic proteinase complex, consisting of 15 major subunits [41, 42] involved in the ATP-dependent proteolysis of ubiquitylated intracellular proteins. The proteasome has been shown to play key roles in a variety of important intracellular events, among which the proteolytic activation of specific signalling molecules, including that of cell cycle progression and apoptosis [43], destruction of abnormal and misfolded proteins, generation of antigen fragments for presentation by class I major histocompatibility complex [42], angiogenesis [44], cell migration, matrix metalloproteinase-9 production and tumor invasion [45]. Recent work reviewed by Spataro et al. [46] has shown that the proteasome/ubiquitine pathway is "often the target of cancer-related deregulation and can underlie processes such as oncogenic transformation, tumour progression, escape from immune surveillance and drug resistance".

The galectins (S-type lectins) are a family of low-molecular weight, calcium-independent, betagalactoside-binding proteins [47], which have been found involved in many cellular functions. These include cell growth and activation, cell-cell and cell-matrix adhesion, as well as binding to carcinoembryonic antigens, laminin and metalloproteinase. The exact role of galectins in cancer progression is controversial, since an increased expression of galectin 1 and 3 has been described in colon carcinomas [48] while a reduced expression of galectin-3 has been reported for breast cancer [49]. 
The annexin I belongs to a family of structurally related, water-soluble proteins that have calciumand phospholipid-binding domains. Recently it has been reported that annexin I expression might correlate with breast cancer development [50].

At present we have no indication on the differential expression of galectin, annexin and proteasome subunit with respect to the tumoral tissues, since these peptides were not identified in the breast tissue maps.

Finally the last group contains proteins, which were identified in the map of the 8701-BC cells, but were absent from the data banks, or with unknown or N-terminal blocked sequences. It is interesting to notice that some of them are absent in the healthy tissues, and therefore are potential also markers of breast cancer.

In conclusion present approach, based on the direct analysis of protein pattern expression, combined with integrated computer tools, has provided the possibility to highlight relevant differences and homologies between cancer cells and tissue, including the identification of a panel of tumor markers of peculiar cellular origin, which collectively may be considered characteristc, if not exclusive, for ductal infiltrating carcinoma of the breast. It is interesting to note that this panel comprehends in prevalence stress proteins and some peptides and factors involved in cellular metabolism, reflecting differential gene expression between different breast cell lines and normal cell lines (see: http://www.anl.gov:80/ $\mathrm{BIO} / \mathrm{PMG} /$ projects/index-hbreast.html).

The extension of this approach to a larger number of cells and tissues, would greatly contribute to understand functional genomics of cancer, and it might provide, in the future, diagnostic or prognostic markers, as well as molecular targets for therapy.

\section{Acknowledgements}

This work was supported by AIRC and MURST (to I.P.M.) We thank Dr Sabrina Liberatori (University of Siena) and Dr. Sabrina Sgroi (University of Palermo) for help with the 2D-IPG preparations, and Dr. Silvana Caricato (Centre of Exp.OncoBiology, Palermo) for technical assistance in cell culture preparation.

\section{References}

1. Donegan W.L.: Tumor-Related Prognostic Factors for Breast Cancer Cancer. J. Clin. 1997, 47: 28-51. 
2. Fields C, Adams M. D, White O, Venter J. C.: How many genes in the human genome?. Nat.Genet. 1994, 7: 345-346.

3. Anderson L, Seilhamer J: A comparison of selected mRNA and protein abundances in human liver. Electrophoresis. 1997, 18: 533-537.

4. Minafra S, Morello V, Glorioso F, La Fiura A. M, Tomasino R. M, Feo S, McIntosh D, Woolley D. E: A new cell line (8701-BC) from primary ductal infiltrating carcinoma of human breast. Br. J. Cancer. 1989, 60: 185-192.

5. Chou J. L, Shen Z. X, Stolfi R. L, Martin D. S, Waxman S: Effects of Extracellular Matrix on the Growth and Casein Gene Expression of Primary Mouse Mammary Tumor Cells in Vitro. Cancer Res. 1989, 49: 5371-5376.

6. Luparello C, Schillaci R, Pucci-Minafra I, Minafra S: Adhesion, growth and cytoskeletal characteristics of 8701-BC breast carcinoma cells cultured in the presence of type V collagen. Eur. J. Cancer. 1990, 26: 231-240.

7. Boudreau N, Werb Z, Bissell M.J: Suppression of apoptosis by basement membrane requires threedimensional tissue organization and withdrawal from the cell cycle. Proc.Natl.Acad.Sci. U.S.A. 1996, 93: 3509-3513.

8. Zetter B. R, Brightman S. E: Cell motility and the extracellular matix. Curr. Opin. in Cell Biol. 1990, 2: $850-856$.

9. Luparello C, Sheterline P, Pucci Minafra I, Minafra S: A comparison of spreading and motility behaviour of 8701-BC breast carcinoma cells on type I, Trimer and type V collagen substrata. Evidence for a permissive effect of type l-trimer on cell locomotion. J. Cell Science. 1991, 100: 179-185.

10. Klemke R.L, Cai S, Giannini A.L, Gallagher P.J, de Lanerolle P, Cheresh D.A: Regulation of cell motility by mitogen-activated protein kinase. J Cell Biol. 1997, 137: 481-492.

11. Minafra S, Giambelluca C, Andriolo M, Pucci-Minafra I: Cell-Cell and Cell-collagen interactions influence gelatinase production by human breast carcinoma cell line 8701-BC. Int. J. of Cancer. 1995, 62: $1-7$.

12. Bini L, Pallini V, Hochstrasser D. F, Tosi P, Magi B, Marzocchi B, Arcuri F, Tripodi S, Cintorino M, Sanchez J. C, Frutiger S, Hughes G: Protein expression profiles in human breast ductal carcinoma and histologically normal tissue. Electrophoresis. 1997, 18: 2832-2841.

13. Görg A, Postel W, Gunther S: The current state of two dimensional electrophoresis with immobilized pH gradient. Electrophoresis. 1988, 9: 531-546.

14. Bjellqvist B, Pasquali C, Ravier F, Sanchez J. C, Hochstrasser D. F: A non linear wide-range immobilized $\mathrm{pH}$ gradient for two dimensional electrophoresis and its definition in a relevant $\mathrm{pH}$ scale. Electrophoresis. 1993, 14: 1357-1365. 
15. Hochstrasser D. F, Harrington M. G, Hochstrasser A. C, Miller M. J, Merril C. R: Methods for increasing the resolution of two dimensional protein electrophoresis. Anal. Biochem. 1988, 173: 424-435.

16. Sanchez J. C, Rouge V, Pisteur M, Ravier F, Tonella L, Moosmayer M, Wilkins M. R, Hochstrasser D. F: Improved and simplified in gel sample application using reswelling of dry immobilized $\mathrm{pH}$ gradients. Electrophoresis. 1997, 18: 324-327.

17. Pucci-Minafra 1, Minafra S, Faccini A. M, Alessandro R: An ultrastructural evaluation of cell heterogeneity in invasive ductal carcinomas of the human breast. J.Submicrosc. Cytol. Pathol. 1989, 21: $475-488$.

18. Luparello C, Noel A, Pucci-Minafra I: Intratumoral heterogeneity for hsp90 beta mRNA levels in a breast cancer cell line. DNA and Cell Biol. 1997, 16: 1231-1236.

19. Alessandro R, Minafra S, Pucci Minafra I, Onisto M, Garbisa S, Melchiori A, Tetlow L, Woolley D. E: Metalloproteinase and Timp expression by the human breast carcinoma cell line 8701-BC. Int. J. Cancer. 1993, 55: 250-255.

20. Luparello C, Ginty A. F, Gallagher J. A, Pucci-Minafra I, Minafra S: TGF-beta, urokinase and PTHrP expression in 8701-BC breast cancer cells and clones. Differentiation. 1993, 55: 73-80.

21. Pucci-Minafra I, Luparello C, Aquino A, Basiricò L, Minafra S, Franc S, Yakovlev L, Shoshan S: OF/LB collagen promotes chemoinvasion of breast cancer cells and directes epithelial cell migration into granulation tissue of experimental dermal wounds. Int. J. of Oncol. 1995, 6: 1015-1020.

22. Pucci-Minafra I, Luparello C, Andriolo M, Basirico' L, Aquino A, Minafra S: A new form of Tumor and Foetal Collagen with Laminin-Binding property. Biochemistry. 1993, 32: 7421-7427.

23. Pucci-Minafra I, Andriolo M, Basiricò L, Aquino A, Minafra S, Boutillon M. M, vander Rest M: Onco-Fetal/Laminin-Binding collagen from colon carcinoma: detection of new sequences. Biochem. Biophys. Res. Commun. 1995, 207: 852-859.

24. Pucci-Minafra I, Luparello C: Type V / Type I collagen interactions 'in vitro' and growth-inhibitory effect of hybrid substrates on 8701-BC carcinoma cells. J.Submicrosc. Cytol. Pathol. 1991, 23: 67-74.

25. Luparello C: Adhesion to type V collagen and cloning efficiency in agar of 8701-BC breast cancer cells. Eur. J. Cancer. 1994, 30A: 1400-1401.

26. Taylor-Papadimitriou J, Stampfer M, Bartek J, Lewis A, Boshell M, Lane E. B, Leigh I. M: Keratin expression in human mammary epithelial cells cultured from normal and malignant tissue: relation to in vivo phenotypes and influence of medium. J. Cell Sci. 1989, 94: 403-413.

27. Desprez P. Y, Poujol D, Saez S: Glyceraldehyde-3-phosphate dehydrogenase (GAPDH, E.C. 1.2.1.12.) gene expression in two malignant human mammary epithelial cell lines: BT-20 and MCF-7. Regulation of gene expression by 1,25-dihydroxyvitamin D3 (1,25-(OH)2D3). Cancer Lett . 1992, 64: 219-224. 
28. Gautron S, Maire P, Hakirn V, Kahn A: Regulation of the multiple promoters of the human aldolase A gene: response of its two ubiquitous promoters to agents promoting cell proliferation. Nucleic Acids Res. 1991, 19: 767-774.

29. Epner D. E, Partin A. W, Schalken J. A, Isaacs J. T, Coffey D. S: Association of glyceraldehyde-3-phosphate dehydrogenase expression with cell motility and metastatic potential of rat prostatic adenocarcinoma. Cancer Res. 1993, 53: 1995-1997.

30. Wang F. L, Wang Y, Wong W. K, Liu Y, Addivinola F. J, Liang P, Chen L. B, Kantoff P. W, Pardee A. B: Two differentially expressed genes in normal human prostate tissue and in carcinoma. Cancer Res. 1996, 56: 3634-3637.

31. Nakai A, Satoh M, Hirayoshi K, Nagata K: Involvement of the stress protein HSP47 in procollagen processing in the endoplasmic reticulum. J. Cell Biol. 1992, 117: 903-914.

32. Satoh M, Hirayoshi K, Yokota S, Hosokawa N, Nagata K: Intracellular interaction of collagenspecific stress protein HSP47 with newly synthesized procollagen. J. Cell Biol. 1996, 133: 469-483.

33. Morino M, Tsuzuki T, Ishikawa Y, Shirakami T, Yoshimura M, Kiyosuke Y, Matsunaga K, Yoshikumi C, Saijo N: Specific expression of HSP47 in human tumor cell lines in vitro. In Vivo. 1997, 11: 17-21.

34. Minafra S, Luparello C, Rallo F, Pucci-Minafra I: Collagen biosynthesis by a breast carcinoma cell strain and biopsy fragments of the primary tumor. Cell Biol Int. Rep. 1988, 12: 895-905.

35. Meyer-Siegler K, Fattor R. A, Hudson P. B: Expression of macrophage migration inhibitory factor in the human prostate. Diagn. Mol. Pathol. 1998, 7: 44-50.

36. Powis G, Kirkpatrick D. L, Angulo M, Baker A: Thioredoxin redox control of cell growth and death and the effects inhibitors. Chem. Biol. Interact. 1998, 24: 23-34.

37. Gallegos A, Gasdaska J. R, Taylor C. W, Paine Murrieta G. D, Goodman D, Gasdaska P. Y, Berggren M, Briehl M. M, Powis G: Transfection with human thioredoxin increases cell proliferation and a dominant-negative mutant thioredoxin reverses the transformed phenotype of human breast cancer cells. Cancer Res. 1996, 56: 5765-5770.

38. Lösch A, Tempfer C, Kohlberger P, Joura E. A, Denk M, Zajic B, Breitenecker G, Kainz C: Prognostic value of cathepsin D expression and association with histomorphological subtypes in breast cancer. Br J Cancer. 1998, 78: 205-209.

39. öohm H, Benndorf R, Gaestel M, Gross B, Nürnberg P, Kraft R, Otto A, Bielka H: The growthrelated protein $\mathrm{P} 23$ of the Ehrlich ascites tumor: translational control, cloning and primary structure. Biochem. Int. 1989, 19: 277-286.

40. Makrides S, Chitpatima S. T, Bandyopadhyay R, Brawerman G: Nucleotide sequence for a major messenger RNA for a 40 kilodalton polypeptide that is under translational control in mouse tumor cells. Nucleic Acids Res. 1988, 16: 2349-2349. 
41. Orlowsky M: The Multicatalytic Proteinase Complex, a Major Extralysosomal Proteolytic System. Biochemistry. 1990, 29: 10289-10297.

42. Krinsten P, Johnsen A. H, Uerkvitz W, Tanaka K, Hendil K. B: Human Proteasome Subunits from 2-Dimensional Gels Identified by Partial Sequencing. Biochem. Biophys. Res.Commun. 1994, 205 : 1785-1789.

43. Maki C. G, Huibregtse J. M, Howley P. M: In vivo ubiquitination and proteasome-mediated degradation of p53. Cancer Res. 1996, 56: 2649-2654.

44. Oikawa T, Sasaki T, Nakamura M, Shimamura M, Tanahashi N, Omura S, Tanaka K: The proteasome is involved in angiogenesis. Biochem. Biophys. Res. Commun. 1998, 246: 243-248.

45. Ikebe T, Takeuchi H, Jimi E, Beppu M, Shinohara M, Shirasuna K: Involvement of proteasomes in migration and matrix metalloproteinase-9 production of oral squamous cell carcinoma. Int. J. Cancer. 1998, 77: 578-585.

46. Spataro V, Norbury C, Harris A. L: The ubiquitin-proteasome pathway in cancer. Br. J. Cancer. 1998, 77: 448-455.

47. Lutomski D, Caron M, Cornillot J. D, Bourin P, Dupuy C, Pontet M, Bladier D, Joubert-Caron R: Identification of different galectins by immunoblotting after two- dimensional polyacrylamide get electrophoresis with immobilized pH gradients. Electrophoresis. 1996, 17: 600-606.

48. Sanjuán X, Fernández P. L, Castells A, Castronovo V, Van den Brule F, Liu F. T, Cardesa A, Campo E: Differential expression of galectin 3 and galectin 1 in colorectal cancer progression. Gastroenterology. 1997, 113: 1906-1915.

49. Idikio H: Galectin-3 expression in human breast carcinoma: correlation with cancer histologic grade. Int. J. Oncol. 1998, 12: 1287-1290.

50. Ahn S. H, Sawada H, Ro J. Y, Nicolson G. L: Differential expression of annexin I in human mammary ductal epithelial cells in normal and benign and malignant breast tissues. Clin. Exp. Metastasis. 1997, 15: 151-156.

\section{Image Object}

1. MediaObjects/13058_1999_Article_31_Fig1_HTML.jpg

2. MediaObjects/13058_1999_Article_31_Fig2_HTML.jpg

3. MediaObjects/13058_1999_Article_31_Fig3_HTML.jpg

4. MediaObjects/13058_1999_Article_31_Fig4_HTML.jpg

5. MediaObjects/13058_1999_Article_31_Fig5_HTML.jpg 